\title{
IDENTIFIKASI MINERAL PEMBAWA HARA UNTUK MENILAI POTENSI KESUBURAN TANAH
}

\author{
Mineral Identification For Nutrients Potential To Assess Soil Fertility \\ ${ }^{1 *}$ Indryani Bali, ${ }^{2}$ Asmita Ahmad, ${ }^{2}$ Christianto Lopulisa \\ ${ }^{1}$ Alumni Jurusan Ilmu Tanah, Fakultas Pertanian, Universitas Hasanuddin, Makassar \\ ${ }^{2}$ Jurusan Ilmu Tanah, Fakultas Pertanian, Universitas Hasanuddin, Makassar \\ ${ }^{*}$ Corresponding email: indryanibali@yahoo.co.id
}

\begin{abstract}
Soil minerals are very important for plants and can be use to assess the potential of soil fertility. This study aims to assess the potential of soil fertility based on mineral identification in Banggae and Eastern Banggae Subdistrict, Majene District, West Sulawesi Province. The method used in this research is descriptive quantitative, by identifying the minerals in the parent material and soil from thin section using polarizing microscope, quantification method for minerals percentage, and classified of nutrient potential with percentage of mineral content reduced by the percentage content of the quartz. The results showed that the dominant mineral found in the parent material and soil are pyroxene, plagioclase, hornblende, biotite, calcite, quartz and opaque, but the size of mineral are smaller than in the parent material. Potential of nutrients generated in the form of weatherable minerals are biotite, calcite, plagioclase, hornblende and pyroxene containing elements such as $\mathrm{Mg}, \mathrm{Ca}, \mathrm{K}, \mathrm{Fe}$ and $\mathrm{Na}$. Potential soil fertility in parent material currently on the moderate criteria ( $48 \%$ to $70 \%$ ), while on the soil with middle criteria (48\% to $70 \%$ ) in P1L1, P2L1, P4L1, P8L1, P9L1, P10L1, P11L1 and P11L2 and good criteria (73\% to $79 \%$ ) in P3L1, P3L2, P4L2, P5L1, P5L2, P6L1, P7L1 and P9L2. Potential nutrient contained in the mineral is not available for plants, because it has not been supported by external factors such as the low availability of water. This is due to the climate condition especially rainfall in
\end{abstract}

research area is in the range of 949.0 to $2557.1 \mathrm{~mm} /$ year with an average annual rainfall of $1608.0 \mathrm{~mm} /$ year.

Keywords: Minerals, nutrients, soil fertility, Majene

\section{PENDAHULUAN}

Tanah terbentuk dari perubahan batuan induk menjadi bahan induk yang dipengaruhi oleh faktor-faktor pendukung lainnya, seperti iklim, relief, organisme dan waktu (Sugiharyanto dan Khotimah, 2009). Proses pembentukan tanah berlangsung dengan berbagai reaksi fisik, kimia dan biologi. Reaksi ini menghasilkan sifat-sifat tanah yang dapat menjalankan fungsi-fungsi tertentu diantaranya: mengubah bahan mentah menjadi bahan induk tanah, mengubah bahan induk tanah menjadi bahan penyusun tanah, dan menata bahan penyusun tanah menjadi tubuh tanah (Notohadiprawiro, 1991).

Mineral yang terkandung dalam tanah dapat berperan cukup potensial di bidang pertanian, karena di dalam beberapa mineral dari batuan terkandung unsur-unsur penting, yang dapat digunakan untuk mempertahankan dan menambah produktivitas lahan maupun hasil pertanian, yang disebut sebagai agromineral. Secara alamiah, proses-proses pelapukan biologi, kimia dan fisika dapat melapukkan batuan menjadi tanah sehingga menguraikan unsur hara bagi tanaman atau tumbuhan. Tanaman memerlukan hara untuk tumbuh, diantaranya 
$\mathrm{N}, \mathrm{P}, \mathrm{K}, \mathrm{Ca}, \mathrm{Mg}$ dan mikroelemen lain yang tidak dimiliki oleh tanah yang kurang subur (Basyuni, 2009).

Kandungan hara yang terdapat dalam suatu mineral ini akan mendukung keberlanjutan dari kesuburan lahan. Dalam menilai potensi lahan, dapat dinilai dari unsur kimia yang dikandungnya. Menurut Pramuji dan Bastaman (2009), untuk mengetahui tingkat cadangan sumber hara dari suatu jenis tanah, diperlukan analisis susunan mineral primer tanah. Dengan mengetahui jumlah tanah yang mengandung mineral mudah lapuk dapat diartikan bahwa tanah tersebut memiliki cadangan sumber hara yang tinggi. Namun, bila dominan adalah mineral tahan lapuk maka contoh tanah tersebut miskin sumber hara.

Dalam konsep kesuburan tanah, pada dasarnya mengkaji kemampuan suatu tanah untuk menyuplai unsur hara yang tersedia bagi tanaman dalam mendukung pertumbuhan dan produksi tanaman. Secara umum semua unsur hara atau nutrient bersumber dari batuan induk serta mineralmineral yang terdapat didalamnya (Lahuddin, 2007).

Mineral yang terdapat didalam tanah berbeda-beda pada setiap wilayah. Kandungan mineral dalam tanah berpengaruh besar terhadap hara yang dikandungnya. Perbedaan ini sangat dipengaruhi oleh bahan induk pembentuknya serta proses-proses kimia dan biokimia yang terjadi dalam tanah. Di dalam tanah biasanya terdapat dua jenis mineral, dikenal sebagai mineral primer dan mineral sekunder. Mineral primer merupakan mineral yang terkristalisasi selama proses pembekuan magma, sedangkan mineral sekunder adalah mineral yang terbentuk melalui proses pelapukan mineral primer, ataupun sebagai hasil proses penambahan yang terjadi pada mineral primer (Mulyanto, 2012).

Pulau Sulawesi dan pulau-pulau kecil di sekitarnya mempunyai kondisi geologi yang kompleks. Hal ini disebabkan kawasan Pulau Sulawesi merupakan tempat tumpukan aktif dari tiga lempeng yaitu Lempeng Hindia-Australia yang bergerak relatif ke arah utara, Lempeng Samudera Pasifik bergerak relatif ke barat dan Lempeng Benua Eurasia yang relatif diam. Tumbukan ketiganya mengakibatkan terdapat komposisi batuan yang beragam (Alam et al., 2012).

Menurut Djuri et al. (1998) dalam Peta Geologi Lembar Majene dan Bagian Barat Lembar Palopo, Sulawesi Edisi Kedua kondisi geologi Kecamatan Banggae dan Banggae Timur antara lain meliputi formasi Qa (Aluvium), Tmpm (Mapi), Tmm (Mandar) dan Qpps (Napal Pambuang).

Kabupaten Majene dibangun oleh wilayah yang topografinya bervariasi dari datar sampai berbukit dan bergunung, dengan kemiringan lereng kurang dari 3\% sampai lebih dari 70\%. Hamparan daerah dengan topografi datar ditemukan di sepanjang wilayah paralel dengan garis pantai kabupaten ini. Hamparan wilayah datar terutama ditemukan mulai dari pantai barat Kecamatan Sendana menuju ke selatan sampai ke Kecamatan Banggae dan Banggae Timur (Ibukota Kabupaten). Sebagian besar wilayah Kabupaten Majene dengan topografi berbukit dan bergunung (Pemkab Majene, 2012).

Melihat betapa pentingnya peranan mineral tanah dalam menilai potensi kesuburan tanah bagi tanaman pada penjelasan diatas, maka dianggap perlu untuk melakukan penelitian yang berjudul "Identifikasi Mineral Pembawa Hara untuk Menilai Potensi Kesuburan Tanah di Kecamatan Banggae dan Banggae Timur”.

\section{METODE PENELITIAN}

Pengamatan dan deskripsi profil serta pengambilan sampel tanah dan bahan induk dilaksanakan di Kecamatan Banggae dan Banggae Timur, Kabupaten Majene, Sulawesi Barat. Analisis mineralogi tanah dan bahan induk dilakukan di Laboratorium Petrografi, Jurusan Teknik Geologi, Fakultas Teknik, Universitas Hasanuddin. 
Analisis sifat fisik dan kimia tanah dilakukan di Laboratorium Kimia Tanah, Departemen Ilmu Tanah, Fakultas Pertanian, Universitas Hasanuddin.

Alat yang digunakan dalam analisis mineral tanah dan bahan induk, analisis sifat fisik dan kimia tanah ditunjukkan pada Tabel 1, sedangkan bahan yang digunakan adalah Sampel tanah utuh kubiena box, sampel tanah terganggu Sampel bahan induk, DIP (Daftar Isian Profil), Peta Rupa Bumi lembar Majene skala 1:50.000, peta geologi Kecamatan Banggae dan Banggae Timur skala 1:50.000, peta administrasi Kecamatan Banggae dan Banggae Timur skala 1:50.000 dan peta lereng Kecamatan Banggae dan Banggae Timur skala 1:50.000, dan Aplikasi ArcGIS 10.1, secara lengkap ditunjukkan pada Tabel 2.

Tabel 1. Alat-alat yang digunakan dalam analisis sampel tanah di laboratorium

\begin{tabular}{lll}
\hline No & Jenis Analisis & Peralatan \\
\hline 1. & Mineral tanah & Mikroskop polarisasi tipe Olympus BX41 \\
2. & $\begin{array}{l}\text { Sifat fisik tanah } \\
\text { Tekstur }\end{array}$ & $\begin{array}{l}\text { Silinder sedimentasi } 800 \mathrm{ml} \text {, peny aring, ay akan } 50 \\
\text { mikron, gelas ukur } 500 \mathrm{ml} \text {, neraca analitik, mortar, } \\
\text { labu semprot, stop watch, termometer dan } \\
\text { hy drometer. }\end{array}$ \\
3. & $\begin{array}{l}\text { Sifat kimia tanah } \\
\text { C-Organik }\end{array}$ & $\begin{array}{l}\text { Labu ukur } 250 \mathrm{ml} \text {, gelas ukur } 10 \mathrm{ml} \text {, pipet volume } \\
50 \mathrm{ml}, \text { pipet tetes, mortar. }\end{array}$ \\
& $\begin{array}{l}\text { Neraca analitik, botol kocok } 50 \mathrm{ml}, \text { mesin } \\
\text { pengocok, mortar, pH meter. }\end{array}$ \\
\hline
\end{tabular}

Tabel 2. Bahan kimia/pereaksi yang digunakan dalam analisis sampel tanah

\begin{tabular}{lll}
\hline No & \multicolumn{1}{c}{ Jenis Analisis } & \multicolumn{1}{c}{ Bahan/pereaksi } \\
\hline 1. & $\begin{array}{l}\text { Mineral tanah } \\
\text { 2. }\end{array} \begin{array}{l}\text { Sifat fisik tanah } \\
\text { Tekstur }\end{array}$ & Larutan epoxy dan resin 1:1, preparat serta deglas \\
& & \multicolumn{1}{c}{$\begin{array}{l}\text { Contoh tanah terganggu } 20 \mathrm{~g}, \mathrm{HCl} 2 \mathrm{~N} \text {, larutan } \\
\mathrm{Na}_{4} \mathrm{P}_{2} \mathrm{O}_{7} 4 \% \text {, aquades }\end{array}$} \\
3. & $\begin{array}{l}\text { Sifat kimia tanah } \\
\text { C-Organik }\end{array}$ & $\begin{array}{l}\text { Contoh tanah terganggu } 1 \mathrm{~g}, \mathrm{~K}_{2} \mathrm{Cr}_{2} \mathrm{O}_{7} 1 \mathrm{~N} 5 \mathrm{ml}, \\
\mathrm{H}_{2} \mathrm{SO}_{4} 5 \mathrm{ml} \text { Amonium } \mathrm{Fe} \text { (II) Sulfat } 0.25 \mathrm{~N}, \\
\text { indikator diphenylamine } 5-10 \text { tetes }\end{array}$ \\
& Contoh tanah terganggu $5 \mathrm{~g}$, aquades $12.5 \mathrm{ml}$ \\
&
\end{tabular}

\section{Metode dan Tahapan Penelitian}

Metode yang digunakan dalam penelitian ini adalah metode survei dengan melakukan pengamatan dan pendeskripsian profil di lapangan ditambah dengan hasil analisis laboratorium. Penentuan peta kerja untuk pengamatan di lapangan dibuat berdasarkan peta lereng dan peta geologi Kecamatan Banggae dan Banggae Timur skala 1:50.000, sehingga akan membentuk suatu garis lurus (Metode Transek). Terdapat tiga garis transek yang akan mewakili lokasi penelitian, sehingga jumlah titik profil pengamatan ada sebelas titik. Adapun uraian tahapan penelitian adalah sebagai berikut:

\section{Tahap Persiapan}

Tahap persiapan dalam penelitian ini meliputi studi pustaka untuk mencari beberapa literatur dari berbagai sumber dan konsultasi dengan pembimbing terkait topik penelitian. Pengumpulan berbagai macam peta yang dibutuhkan untuk menunjang survei di lapangan antara lain Peta Rupa Bumi Indonesia lembar Majene skala 1:50.000, Peta Geologi lembar Majene dan bagian Barat Palopo skala 1:250.000, data spasial berupa peta kontur Sulawesi Barat skala 1:200.000 dan Peta Administrasi Kabupaten Majene skala 1:50.000.

\section{Pembuatan Peta Kerja}

Peta kerja merupakan peta yang digunakan sebagai acuan dalam pengambilan atau peletakan lokasi pengamatan. Peta awal yang digunakan adalah peta lereng dan peta geologi. Penentuan titik lokasi pengambilan sampel tanah menggunakan metode transek. Terdapat tiga garis transek yang mewakili lokasi penelitian, sehingga jumlah titik pengambilan sampel sebanyak 11 titik. Selanjutnya dibuatkan penampang melintang agar memudahkan pengambilan sampel di lapangan. Penampang melintang tersebut dibuat dengan menggunakan data 
SRTM (Shuttle Radar Topography Mission) daerah di Kabupaten Majene menggunakan aplikasi ArcGIS 10.1.

\section{Perizinan Lokasi}

Tahapan ini meliputi perizinan lokasi tempat penelitian dari pemerintah setempat yaitu Camat Banggae dan Camat Banggae Timur, agar hal yang tidak diinginkan dapat dihindari.

\section{Survei Lapangan}

Tahapan ini meliputi pencarian titik koordinat yang sama di peta kerja dengan di lapangan, pencatatan ketinggian tempat melaui GPS, dilanjutkan dengan penggalian dan pengamatan profil. Pada profil tanah dilakukan pengamatan penentuan kedalaman lapisan, jumlah lapisan dan lainnya. Selanjutnya dilakukan pengambilan sampel terganggu pada setiap lapisan untuk analisis sifat fisik dan kimia tanah. Pengambilan sampel tanah utuh tiap lapisan tanah dengan menggunakan kubiena box dan sampel bahan induk untuk analisis mineralogi tanah. Semua sampel diberi label agar mudah dibedakan antara sampel yang satu dan sampel lainnya.

\section{Analisis Laboratorium}

Pada tahapan ini sebelum dilakukan analisis, beberapa contoh tanah dikering udarakan. Selanjutnya dilakukan analisis sifat fisik dan kimia sampel tanah di laboratorium. Adapun parameter yang dianalisis beserta metodenya pada penelitian ini ditunjukkan pada Tabel 3 .

Tabel 3. Jenis dan metode analisis tanah di Laboratorium.

\begin{tabular}{|c|c|c|}
\hline No & Parameter & Metode \\
\hline 1. & Mineral tanah & Petrografi \\
\hline 2. & Sifat fisik tanah & Hydrometer \\
\hline 3. & Sifat kimia tanah & \\
\hline & $\begin{array}{l}\text { C-Organik } \\
\text { pH }\end{array}$ & $\begin{array}{l}\text { Walkey and Black } \\
\text { pH Meter }\end{array}$ \\
\hline
\end{tabular}

\section{Tahap Identifikasi Mineral}

Adapun tahapan identifikasi mineral pada penelitian ini, yaitu: 1) Mengamati mineral sayatan tipis (thin section) pada sampel tanah dan bahan induk dengan ketebalan $0.03 \mathrm{~mm}$ pada mikroskop polarisasi perbesaran 40x, 2) Memutar meja objek sampai diperoleh warna interferensi maksimum kemudian mendokumentasikan gambar hasil nikol sejajar dan nikol silang, 3) Melakukan pendeskripsian hasil foto nikol sejajar berupa warna mineral, 4) Melakukan pendeskripsian hasil foto nikol silang berupa warna interferensi berdasarkan Michel-Levy color chart, 5) Menarik garis melalui ketebalan $0.03 \mathrm{~mm}$ dan garis diagonal yaitu sifat birefringence $(\mathrm{BF})$, dari posisi BF luruskan ke bawah melalui garis diagonal ke perpotongannya, 6) Menentukan nama mineral berdasarkan warna yang telah ditentukan.

\section{Penilaian Potensi Kesuburan}

Setelah mengetahui hasil identifikasi mineral pada tiap lapisan di beberapa profil tanah, pada tahapan ini dilanjutkan dengan menggunakan metode mineral counting pada sayatan tipis. Metode mineral counting adalah perhitungan jumlah mineral dalam satu bidang pengamatan, diasumsikan jumlahnya adalah $100 \%$. Proses ini meliputi persentase mineral mudah lapuk (weatherable mineral) dan mineral resisten (resistant mineral), selanjutnya dipersentasekan keberadaan mineralnya. Setelah melewati tahap persentase, maka akan diketahui mineral mana yang paling dominan. Dengan mengetahui mineral dominan yang terkandung, secara tidak langsung dapat diketahui pula potensi keharaan yang terkandung dalam mineral tersebut. Senyawa kimia penyusun mineral inilah yang selanjutnya akan dikategorikan sebagai unsur hara makro maupun mikro yang dibutuhkan bagi tanaman.

Menurut Notohadiprawiro (1983), metode dalam penilaian cadangan hara dalam tanah sangat perlu untuk diketahui. 
Terlepas dari Soil Taxonomy, pembedaan mineral kuarsa dilakukan dalam memperkirakan kandungan mineral terlapukkan (cadangan hara), yaitu:

\section{Cadangan Hara $=100-\%$ kuarsa}

Setelah diketahui persentase mineral lapuk, maka dilakukan penilaian potensi kesuburan pada tiap sampel. Berikut kriteria dalam penilaian potensi kesuburan tanah (Tabel 4).

Tabel 4. Kriteria penilaian potensi kesuburan.

\begin{tabular}{cc}
\hline Mineral Terlapukkan & Sebutan \\
\hline $100 \%-70 \%$ & Baik \\
$70 \%-40 \%$ & Sedang \\
$40 \%-0 \%$ & Buruk \\
\hline
\end{tabular}

Sumber: Notohadiprawiro, (1983).

\section{GAMBARAN UMUM WILAYAH}

\section{Letak Geografis dan Batas Administrasi}

Lokasi penelitian terletak di dua Kecamatan, yang pertama Kecamatan Banggae, Kabupaten Majene, Sulawesi Barat. Titik pengamatan dan pengambilan sampel tanah berada di desa Pamboborang. Secara geografis, daerah ini terletak di $03^{\circ} 32^{\prime} 46^{\prime \prime}$ dan $03^{\circ} 32^{\prime} 16^{\prime \prime} \mathrm{LS}$ dan $118^{\circ} 57^{\prime} 50^{\prime \prime}-118^{\circ}$ 58' 6" BT. Lokasi penelitian yang kedua terletak di Kecamatan Banggae Timur, Kabupaten Majene, Sulawesi Barat. Setiap transek titik pengamatan dan pengambilan sampel tanah berada di desa Baruga, Baruga Dua, Tande dan Tande Timur. Secara geografis, daerah ini terletak di $03^{\circ} 32^{\prime} 32^{\prime \prime}$ LS dan $118^{\circ} 58^{\prime} 28^{\prime \prime} \mathrm{BT}$.

\section{Litologi}

Berdasarkan peta geologi Kecamatan Banggae dan Banggae Timur skala 1:50.000 ditemukan empat jenis formasi geologi. Keempat Formasi disajikan pada Tabel 5 dan Gambar 1.
Tabel 5. Jenis Formasi Batuan Kecamatan Banggae dan Banggae Timur

\begin{tabular}{|c|c|c|c|}
\hline Kode $\left(^{*}\right)$ & Formasi Batuan & Luas (ha) & Persentase (\%) \\
\hline Tmm & Mandar & 783.20 & 12.87 \\
\hline Tmpm & Mapi & 1844.91 & 30.32 \\
\hline Qpps & $\begin{array}{c}\text { Napal } \\
\text { Pambuang }\end{array}$ & 1300.59 & 21.37 \\
\hline Qa & Aluvium & 2156.25 & 35.44 \\
\hline \multicolumn{2}{|c|}{ Luas Total } & 6084.95 & 100 \\
\hline
\end{tabular}

\section{Kelerengan}

Berdasarkan peta lereng skala 1:50.000 (Gambar 2), Kecamatan Banggae dan Banggae Timur memiliki kemiringan lereng yang beragam mulai dari $0 \%$ sampai diatas $70 \%$. Klasifikasi kelerengan didasarkan klasifikasi lereng menurut Van Zuidam (1985).

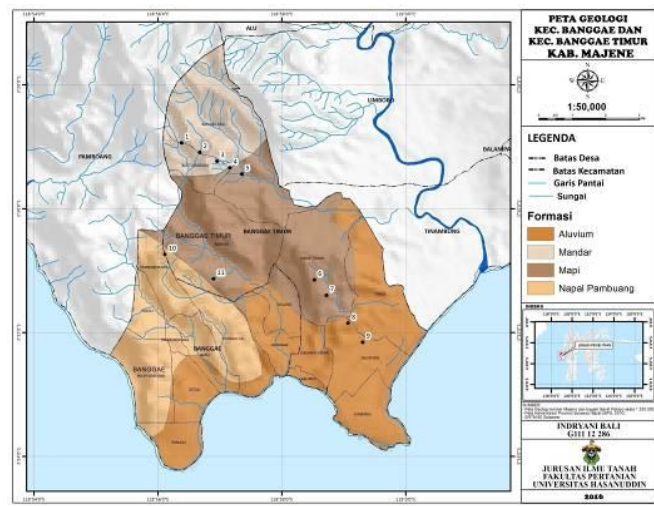

Gambar 1. Peta Geologi Kec. Banggae dan Banggae Timur dengan 11 titik pengambilan sampel.

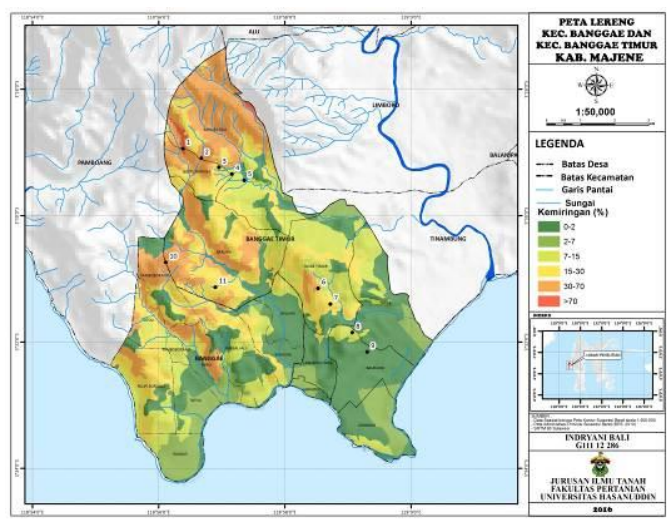

Gambar 2. Peta Lereng Kec. Banggae dan Banggae Timur 


\section{HASIL DAN PEMBAHASAN}

\section{Mineral Pembawa Hara pada Bahan Induk Tanah}

Batuan adalah material alam yang tersusun atas kumpulan (agregat) mineral baik yang terkonsolidasi maupun yang tidak terkonsolidasi yang merupakan penyusun utama kerak bumi serta terbentuk sebagai hasil proses alam. Batuan bisa mengandung satu atau beberapa mineral (Warmana dan Titisari, 2004). Batuan akan melapuk menjadi bahan induk dan secara sempurna akan membentuk tanah, sehingga mineral yang terkandung dalam batuan juga terdapat pada bahan induk dan tanahnya. Dengan mengetahui mineral yang terkandung, maka dapat memberi indikasi jumlah unsur hara yang dikandungnya. Berdasarkan Peta Geologi terdapat empat formasi batuan pada Kecamatan Banggae dan Banggae Timur yaitu Tmpm, Tmm, Qa dan Qpps yang terbagi kedalam tiga transek penelitian dengan profil pewakil yaitu T1P1, T2P6, T2P8 dan T3P10.

\section{Mineral pembawa hara pada Transek I}

Profil 1 merupakan pewakil dalam pengambilan sampel bahan induk pada Transek I dengan formasi geologi Tmm dengan lithologi batupasir, batulanau dan serpih. Jenis mineral kuarsa berwarna putih terang dan pada nikol sejajar tanpa warna. Mineral opak berwarna hitam pada nikol silang maupun nikol sejajar. Piroksin berwarna keunguan pada nikol silang dan tanpa warna pada nikol sejajar. Mineral hornblende berwarna hijau pada nikol silang dan nikol sejajar. Mineral plagioklas berwarna putih abu-abu pada nikol silang dan tanpa warna pada nikol sejajar (Gambar $3)$.

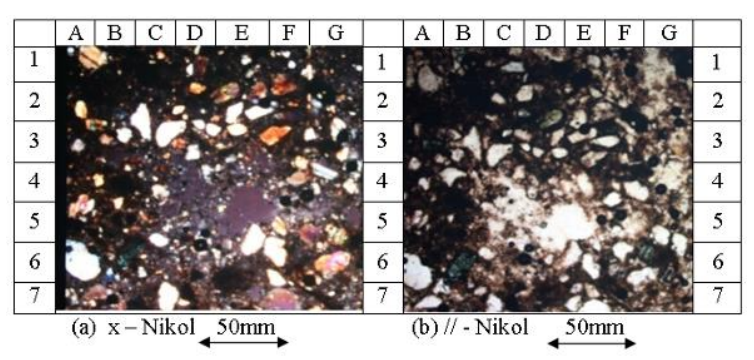

Gambar 3. (a) Sayatan tipis bahan induk profil 1 dengan nikol, (b) Sayatan tipis bahan induk profil 1 tanpa nikol. kuarsa (4B), opak (2G), piroksin (6G), hornblende $(6 \mathrm{~B})$ dan plagioklas (4G).

Berdasarkan hasil identifikasi mineral pada sampel bahan induk profil 1, maka persentase kandungan mineral ditunjukkan pada Tabel 6 .

Tabel 6. Persentase kandungan mineral pada bahan induk profil 1

\begin{tabular}{|c|c|c|c|c|}
\hline $\begin{array}{l}\text { Kode } \\
\text { Profil }\end{array}$ & Lapisan & $\begin{array}{c}\text { Mineral } \\
\text { yang } \\
\text { Terkandung }\end{array}$ & $\begin{array}{l}\text { Kandungan pada } \\
\text { Lapisan (\%) }\end{array}$ & Batuan Induk \\
\hline \multirow{5}{*}{ T1P1 } & \multirow{5}{*}{$\begin{array}{l}\text { Bahan } \\
\text { Induk }\end{array}$} & Kuarsa & 30 & \multirow{5}{*}{ Batupasir, batulanau dan serpih } \\
\hline & & Opak & 20 & \\
\hline & & Piroksin & 23 & \\
\hline & & Plagioklas & 21 & \\
\hline & & Hornblende & 6 & \\
\hline
\end{tabular}

Data diatas menunjukkan bahwa, kuarsa memiliki persentase tertinggi sebesar $30 \%$ dibandingkan mineral lainnya, seperti piroksin yang hanya memiliki persentase $23 \%$, plagioklas $21 \%$ dan hornblende $6 \%$ pada hasil identifikasi mineral sayatan tipis bahan induk profil 1. Dengan demikian, diasumsikan bahwa bahan induk pada profil 1 mempunyai potensi kandungan sumber hara sedang. Karena mineral mudah lapuk seperti piroxin, hornblende dan plagioklas banyak terdapat pada lapisan bahan induk profil 1. Hal ini didukung oleh pernyataan Pramuji dan Bastaman (2009), yang menyatakan bahwa mineral mudah lapuk seperti plagioklas dan piroksin dapat melepaskan unsur hara penyusunnya kedalam tanah seperti $\mathrm{Ca}$ dan $\mathrm{Mg}$. 


\section{Mineral pembawa hara pada Transek II}

Pada Transek II terdapat dua formasi geologi yaitu Tmpm pada profil 6 sebagai pewakil untuk lithologi batupasir tufaan, batulanau, batulempung, batugamping pasiran dan konglomerat, serta formasi geologi Qa pada profil 8 dengan lithologi lempung lanau, pasir dan kerikil. Berikut penjelasannya:

\section{Profil 6}

Mineral yang terdapat pada lapisan bahan induk profil 6 antara lain biotit (6D), kalsit (3E) dan kuarsa (6B). Biotit berwarna coklat kemerahan pada nikol silang dan berwarna coklat pada nikol sejajar. Kalsit memiliki warna interferensi 0.028-0.015 dan berwarna putih pada nikol sejajar. Kuarsa berwarna putih terang pada nikol silang dan tanpa warna pada nikol sejajar (Gambar 4).

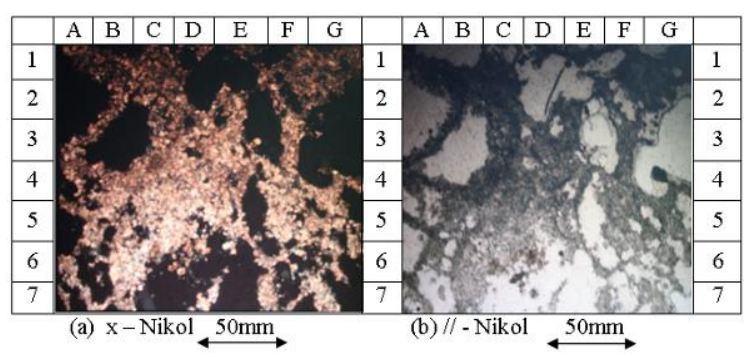

Gambar 4. (a) Sayatan tipis bahan induk profil 6 dengan nikol, (b) Sayatan tipis bahan induk profil 6 tanpa nikol. biotit (6D), kalsit (3E) dan kuarsa (6B).

Berdasarkan hasil identifikasi mineral pada sampel bahan induk profil 6 , maka persentase kandungan mineral ditunjukkan pada Tabel 7.

Tabel 7. Persentase kandungan mineral pada bahan induk profil 6

\begin{tabular}{|c|c|c|c|c|}
\hline $\begin{array}{l}\text { Kode } \\
\text { Profil }\end{array}$ & Lapisan & $\begin{array}{c}\text { Mineral } \\
\text { yang } \\
\text { Terkandung }\end{array}$ & $\begin{array}{l}\text { Kandungan pada } \\
\text { Lapisan (\%) }\end{array}$ & Batuan Induk \\
\hline \multirow{3}{*}{ T2P6 } & \multirow{3}{*}{$\begin{array}{c}\text { Bahan } \\
\text { Induk }\end{array}$} & Kuarsa & 52 & \multirow{3}{*}{$\begin{array}{c}\text { batupasir tufaan, batulanau } \\
\text { batulempung, batugamping } \\
\text { pasiran dan konglomerat }\end{array}$} \\
\hline & & Kalsit & 35 & \\
\hline & & Biotit & 9 & \\
\hline
\end{tabular}

Data diatas menunjukkan bahwa persentase tertinggi didominasi oleh mineral kuarsa dengan persentase 52\%, dibandingkan dengan mineral kalsit 35\% dan biotit sebesar 9\%. Hal ini dibuktikan dengan adanya peranan dari batuan induk berupa batupasir tufaan dan batugamping pasiran sebagai penyusun tanah pada profil 6 yang mengandung mineral kuarsa. Batugamping juga memengaruhi persebaran mineral kalsit pada bahan induk profil 6 . Berdasarkan hasil analisis AAS oleh Djuhariningrum dan Rusmadi (2004) diperoleh hasil yaitu mineral penyusun batugamping paling dominan adalah mineral kalsit dengan kadar 82\% sampai 90\% dengan senyawa penyusunya yang terdiri dari kalsium (Ca) dan karbonat $\left(\mathrm{CO}_{3}\right)$. Mineral kalsit merupakan mineral sekunder yang masuk kedalam kelompok karbonat, memiliki sifat mudah lapuk dalam tanah.

Menurut Alamudi (2014), kalsit merupakan mineral yang banyak mengandung unsur hara $\mathrm{Ca}$ dalam tanah yang dibutuhkan oleh tanaman, namun ketersediannnya dipengaruhi oleh intensitas curah hujan karena kation-kationnya mudah tercuci.

Namun keberadaan mineral kuarsa yang merupakan mineral tahan lapuk pada lapisan bahan induk profil 6, kurang menguntungkan bagi tanaman. Hal ini mengindikasikan bahwa bahan induk profil 6 memiliki potensi yang sedang.

\section{Profil 8}

Mineral yang banyak terdapat pada bahan induk profil 8 yaitu kuarsa (5C), plagioklas (2D) dan kalsit (4D). Kuarsa berwarna putih terang pada nikol silang dan tanpa warna pada nikol sejajar. Plagioklas berwarna putih pada nikol silang dan tanpa warna pada nikol sejajar. Sedangkan kalsit tanpa warna nikol sejajar (Gambar 5). 


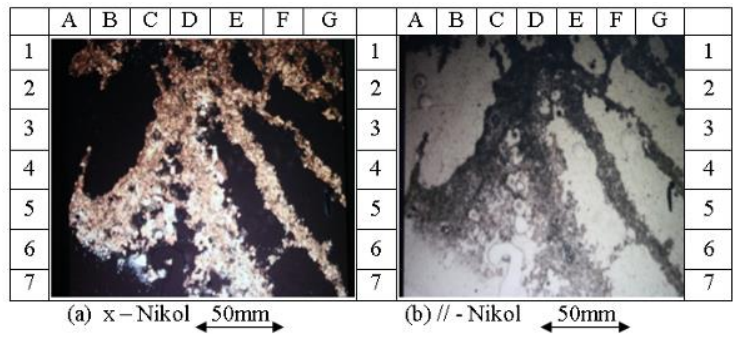

Gambar 5. (a) Sayatan tipis bahan induk profil 8 dengan nikol, (b) Sayatan tipis bahan induk profil 8 tanpa nikol. kuarsa (5C), plagioklas (2D) dan kalsit (4D).

Berdasarkan hasil identifikasi mineral pada sampel bahan induk profil 8 , maka persentase kandungan mineral ditunjukkan pada Tabel 8 .

Tabel 8. Persentase kandungan mineral pada bahan induk profil 8

\begin{tabular}{|c|c|c|c|c|}
\hline $\begin{array}{l}\text { Kode } \\
\text { Profil }\end{array}$ & Lapisan & $\begin{array}{c}\text { Mineral } \\
\text { yang } \\
\text { Terkandung }\end{array}$ & $\begin{array}{l}\text { Kandungan pada } \\
\text { Lapisan (\%) }\end{array}$ & Batuan Induk \\
\hline \multirow{3}{*}{ T2P8 } & \multirow{3}{*}{$\begin{array}{l}\text { Bahan } \\
\text { Induk }\end{array}$} & Kuarsa & 40 & \multirow{3}{*}{$\begin{array}{l}\text { Lempung lanau, pasir dan } \\
\text { kerikil }\end{array}$} \\
\hline & & Feldspar & 26 & \\
\hline & & Kalsit & 34 & \\
\hline
\end{tabular}

Data diatas menunjukkan bahwa, kuarsa menempati persentase tertinggi (40\%), namun persentasenya tak jauh beda dengan mineral kalsit sebanyak $34 \%$ dan feldspar $26 \%$. Hal ini diakibatkan karena profil 8 yang terletak di formasi geologi Qa merupakan daerah aluvium (endapan), sehingga diperoleh batulempung dan batupasir sebagai batuan penyusun profil 8 . Batupasir yang banyak mengandung mineral kuarsa sedangkan batulempung didominasi oleh mineral lempung. Menurut Saptaningsih (2007), mineral primer seperti kuarsa $\left(\mathrm{SiO}_{2}\right)$, tahan terhadap pelapukan dan tidak mampu menyediakan unsur hara.

Jika menilik hasil persentase mineral dalam tabel, maka jumlah persentase mineral mudah lapuk lebih dominan yaitu sebesar $60 \%$. Dengan demikian, diasumsikan bahwa bahan induk pada profil 8 mempunyai potensi kandungan cadangan hara sedang akan unsur $\mathrm{K}$ dan $\mathrm{Ca}$.

\section{Mineral pembawa hara pada Transek III}

Profil 10 merupakan profil pewakil dalam pengambilan contoh bahan induk pada Transek III dengan formasi geologi Qpps berlithologi napal tufaan, serpih napalan, batupasir tufaan, lensa-lensa konglomerat. Jenis mineral yang terdapat pada bahan induk profil 10 yaitu biotit (4D), mineral liat (5F) dan kuarsa (7A). Mineral biotit terlihat jelas pada nikol silang dengan warna coklat kemerahan dan berwarna coklat pada nikol sejajar. Mineral liat berwarna kecoklatan pada nikol silang dan nikol sejajar (Gambar 6).

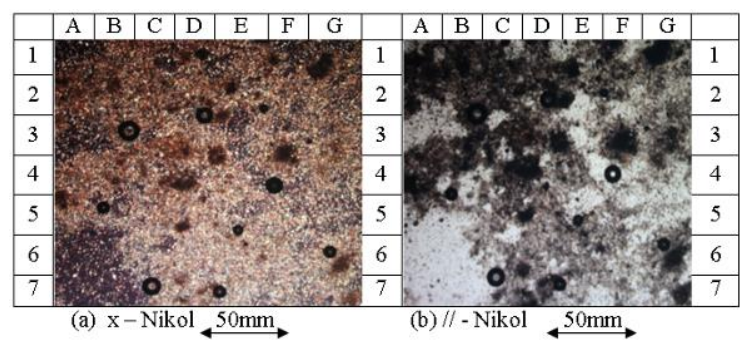

Gambar 6. (a) Sayatan tipis bahan induk rofil 10 dengan nikol, (b) Sayatan tipis bahan induk profil 10 tanpa nikol. biotit (4D), mineral liat $(5 \mathrm{~F})$ dan kuarsa (7A).

Dari hasil identifikasi mineral dapat diketahui bahwa kandungan mineral pada sampel bahan induk profil 10 tertuang pada Tabel 9.

Tabel 9. Persentase kandungan mineral pada bahan induk profil 10 .

\begin{tabular}{|c|c|c|c|c|}
\hline $\begin{array}{l}\text { Kode } \\
\text { Profil }\end{array}$ & Lapisan & $\begin{array}{c}\text { Mineral } \\
\text { yang } \\
\text { Terkandung }\end{array}$ & $\begin{array}{l}\text { Kandungan pada } \\
\text { Lapisan (\%) }\end{array}$ & Batuan Induk \\
\hline \multirow{3}{*}{ T3P10 } & \multirow{3}{*}{$\begin{array}{l}\text { Bahan } \\
\text { Induk }\end{array}$} & Biotit & 37 & \multirow{3}{*}{$\begin{array}{l}\text { napal tufaan, serpih napalan, } \\
\text { batupasir tufaan, lensa-lensa } \\
\text { konglomerat }\end{array}$} \\
\hline & & Kuarsa & 33 & \\
\hline & & Liat & 30 & \\
\hline
\end{tabular}

Berdasarkan tabel diatas persentase mineral biotit $37 \%$ lebih mendominasi, 
namun hasilnya tidak jauh berbeda dengan persentase mineral kuarsa sebesar 33\% dan mineral liat $30 \%$. Mineral biotit dan mineral liat memiliki persamaan yaitu merupakan mineral mudah lapuk, sedangkan kuarsa merupakan mineral primer yang memiliki sifat tahan lapuk. Mineral biotit adalah kelompok mika yang merupakan mineral dengan mengandung unsur hara yang dibutuhkan oleh tanaman seperti unsur Kalsium (K), Magnesium (Mg) dan Besi (Fe). Menurut Aini dan Mulyono (2014), dalam penelitiannya menyebutkan bahwa pada tanah-tanah yang banyak mengandung mineral yang sangat mudah lapuk (early weathering stages) menunjukkan bahwa tanah tersebut masih muda atau belum mengalami pelapukan lanjut. Dengan demikian dapat diasumsikan bahwa mineralmineral pada lapisan bahan induk profil 10 memiliki potensi cadangan hara sebesar $69 \%$ dengan kriteria sedang bagi tanaman.

\section{Mineral Pembawa Hara pada Tanah}

Mineral yang terdapat dalam tanah dapat mengindikasikan berapa banyak hara yang terkandung didalamnya. Pada umumnya mineral tanah yang sering dijumpai pada lokasi penelitian ini adalah biotit, kalsit, plagioklas, piroksin, hornblende, kuarsa, opak dan liat. Berikut adalah hasil dari identifikasi mineral berupa gambar sayatan tipis (thin section) pada setiap profil tanah di beberapa Transek.

\section{Mineral Tanah pada Transek I}

\section{Profil 1}

Profil 1 yang berada pada posisi lereng hanya memiliki satu lapisan tanah dan berwarna terang, jenis mineral yang terdapat pada lapisan 1 profil 1 adalah kuarsa (2B), opak (2D), biotit (2E) dan mineral liat (3C). Mineral kuarsa berwarna putih terang pada nikol silang dan tanpa warna pada nikol sejajar. Mineral opak berwarna hitam pada nikol silang dan nikol sejajar. Mineral biotit jika dilihat pada nikol silang dan nikol sejajar berwarna kecoklatan. Mineralmineral yang sulit diidentifikasi merupakan mineral liat yang berwarna coklat (Tabel 10 dan Gambar 7).

Tabel 10. Persentase kandungan mineral pada profil 1.

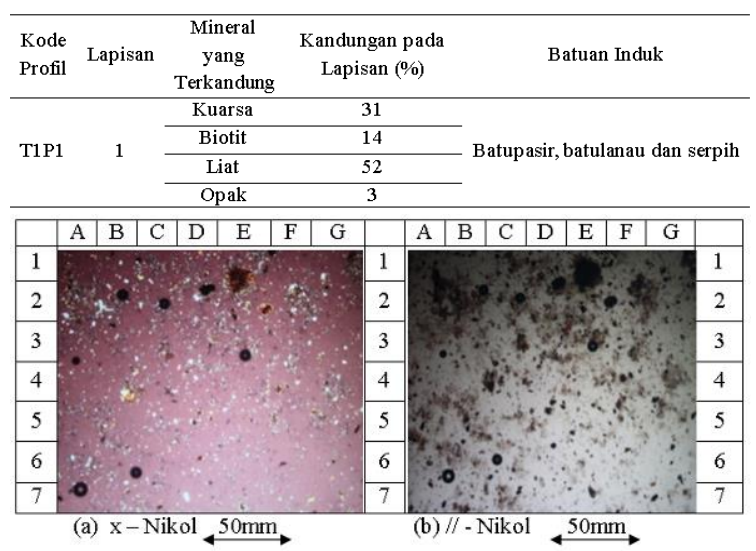

Gambar 7. (a) Sayatan tipis lapisan 1 profil 1 dengan nikol, (b) Sayatan tipis lapisan 1 profil 1 tanpa nikol. kuarsa (2B), opak (2D), biotit (2E) dan mineral liat (3C).

Data diatas menunjukkan bahwa, mineral liat memiliki persentase tertinggi yaitu $52 \%$ dibandingkan mineral kuarsa $31 \%$, biotit $14 \%$ dan opak $3 \%$. Adanya mineral liat dan kuarsa ditandai dari adanya batuan induk berupa batulanau dan batupasir. Jika dibandingkan hasil identifikasi mineral pada bahan induk dan tanah profil 1 yaitu pada bahan induk yang tertinggi adalah persentase mineral primer (80\%), sedangkan pada lapisan 1 didominasi oleh mineral liat (52\%). Hal ini disebabkan karena mineral-mineral primer yang dikandung oleh bahan induk profil 1 melapuk, sehingga terbentuk mineral hasil pembentukan baru yaitu mineral liat pada lapisan 1. Dengan demikian, diasumsikan bahwa bahan induk pada profil 1 mempunyai potensi kandungan sumber hara tinggi.

\section{Profil 2}

Sama halnya dengan profil 1, profil 2 juga 
memiliki satu lapisan tanah sebelum bahan induk. Mineral yang terdapat pada profil 2 lapisan 1 adalah biotit (2C), kuarsa (2D) dan mineral liat. Mineral kuarsa berwarna putih terang pada nikol silang dan tanpa warna pada nikol sejajar. Biotit berwarna kecoklatan pada nikol silang dan nikol sejajar. Pada lapisan ini didominasi oleh mineral liat yang berukuran kecil. Mineral liat digambarkan sebagai mineral yang cukup sulit untuk diidentifikasi pada gambar sayatan tipis (Gambar 8 dan Tabel 11).

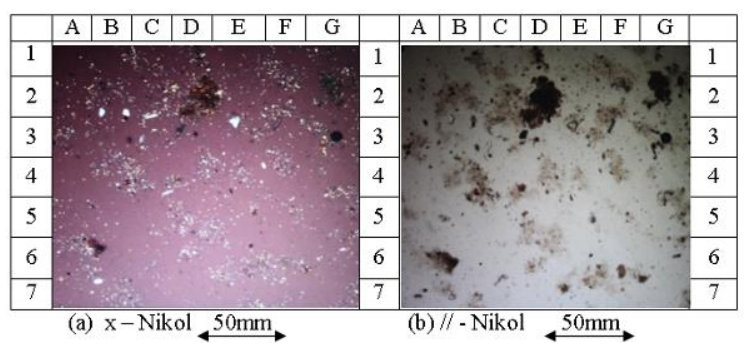

Gambar 8. (a) Sayatan tipis sampel tanah profil 2 dengan nikol, Sayatan tipis sampel tanah profil 2 tanpa nikol. biotit (2C), kuarsa (2D).

Tabel 11. Persentase kandungan mineral pada profil 2.

\begin{tabular}{ccccc}
\hline \multirow{2}{*}{$\begin{array}{c}\text { Kode } \\
\text { Profil }\end{array}$} & Lapisan & $\begin{array}{c}\text { Mineral } \\
\text { yang } \\
\text { Terkandung }\end{array}$ & $\begin{array}{c}\text { Kandungan pada } \\
\text { Lapisan (\%) }\end{array}$ & Batuan Induk \\
\hline \multirow{2}{*}{ T1P2 } & \multirow{2}{*}{1} & Biotit & 19 \\
\cline { 3 - 4 } & Kuarsa & 38 \\
\cline { 2 - 3 } & Liat & 43 & \\
\hline
\end{tabular}

Data diatas menunjukkan bahwa, mineral liat memiliki persentase sebesar 43\% dibandingkan mineral kuarsa 38\% dan biotit $19 \%$. Mineral biotit dan mineral liat memiliki sifat mudah lapuk, sehingga dapat diasumsikan bahwa mineral liat yang terkandung adalah hasil pelapukan dari mineral primer yang terkandung yaitu biotit. Hal ini sependapat dengan Ibrahim dan Ahmad (2012), yang menyatakan bahwa mineral sekunder dihasilkan dari proses pelapukan mineral primer dan hasil ubahan mineral primer. Dengan demikian, dapat diasumsikan bahwa pada profil 2 lapisan 1 memiliki potensi cadangan hara sedang.

\section{Profil 3}

Profil 3 memiliki dua lapisan sebelum lapisan bahan induk. Jenis mineral yang terdapat pada lapisan 1 profil 3 antara lain biotit (3F), kuarsa (7D), plagioklas (3E), hornblende $(5 \mathrm{G})$ dan mineral liat (2B). Mineral biotit terlihat mendominasi pada lapisan 1 profil 4, pada gambar terlihat sebarannya baik ukuran besar maupun ukuran kecil berwarna coklat kemerahan pada nikol silang dan berwarna coklat pada nikol sejajar. Kuarsa berwarna putih terang pada nikol silang dan tanpa warna pada nikol sejajar. Hornblende atau amfibol berwarna coklat kekuningan pada nikol silang dan nikol sejajar. Plagioklas berwarna putih pada nikol silang dan tanpa warna pada nikol sejajar. Mineral liat pada umumnya berwarna coklat pada nikol silang (Gambar 9).

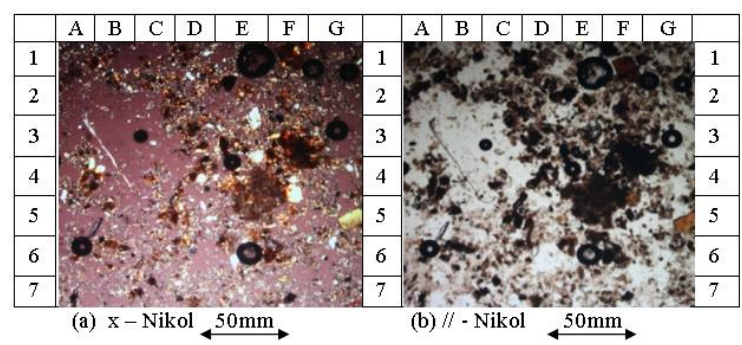

Gambar 9. (a) Sayatan tipis sampel tanah lapisan 1 profil 3 dengan nikol, (b) Sayatan tipis sampel tanah lapisan 1 profil 3 tanpa nikol, biotit (3F), kuarsa (7D), plagioklas (3E), hornblende (5G) dan mineral liat (2B).

Jenis mineral yang terdapat pada lapisan 2 profil 3 antara lain biotit (4A), berwarna coklat kemerahan pada nikol silang dan coklat pada nikol sejajar. Kuarsa (1C) berwarna putih terang pada nikol silang dan tanpa warna pada nikol sejajar. Opak (3D), berwarna hitam pada nikol silang dan nikol sejajar. Mineral hornblende (2F) berwarna biru terang pada nikol silang dan tanpa warna hingga biru pada nikol sejajar. Piroksin (5D) berwarna kuning pada nikol silang dan nikol sejajar (Gambar 10). 


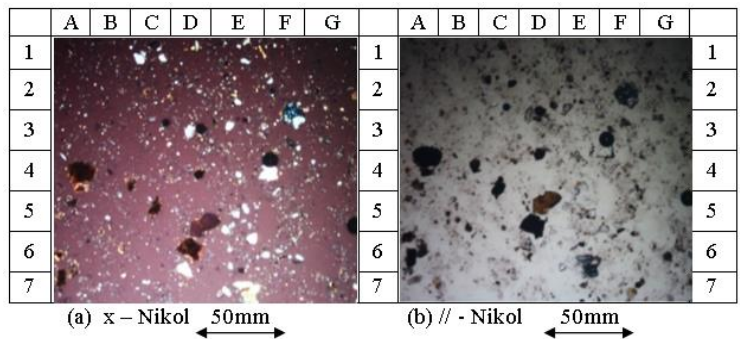

Gambar 10. (a) Sayatan tipis sampel tanah lapisan 2 profil 3 dengan nikol, (b) Sayatan tipis sampel tanah lapisan 2 profil 3 tanpa nikol. biotit (4A), Kuarsa (1C), Opak (3D), Mineral hornblende (2F), dan Piroksin (5D).

Berdasarkan hasil identifikasi mineral pada sampel tanah profil 3, maka persentase kandungan mineral ditunjukkan pada Tabel 12.

Tabel 12. Persentase kandungan mineral pada profil 3

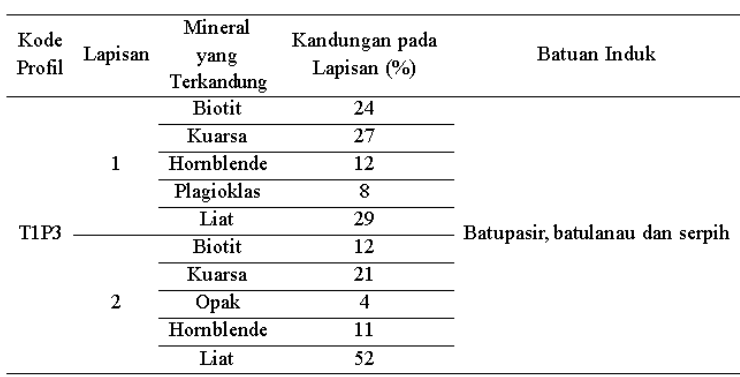

Berdasarkan hasil identifikasi mineral diatas, dapat diketahui bahwa kandungan mineral pada lapisan pertama profil didominasi oleh mineral-mineral mudah lapuk antara lain biotit $24 \%$, hornblende $12 \%$, plagioklas $8 \%$ dan liat $29 \%$. Tingginya kandungan mineral mudah lapuk pada lapisan 1, mensyaratkan bahwa terdapat banyak mineral makro yang dapat diperoleh bagi tanaman. Dengan demikian diasumsikan bahwa pada lapisan 1 profil 3 memiliki potensi hara yang baik seperti $\mathrm{K}$, $\mathrm{Mg}, \mathrm{Fe}, \mathrm{Ca}$ dan $\mathrm{Na}$. Hal ini sependapat dengan Pramuji (2009), menyatakan bahwa pada umumnya mineral primer terdiri dari mineral silikat, kemudian variasinya terdiri dari mineral feldsfar yang mengandung pesenyawaan alumunium, kalsium, natrium, besi dan magnesium.

Pada lapisan dua profil 3 didominasi oleh mineral mudah lapuk dengan persentase mineral biotit sebesar $12 \%$, mineral hornblende $11 \%$ dan liat 52\%. Artinya unsur-unsur hara yang terkandung di dalam mineral dapat diserap oleh tanaman. Saat mengalami pelapukan, walaupun hal ini hanya dapat terjadi jika didukung dengan bantuan air, agar statusnya menjadi tersedia bagi tanaman. Hal ini sesuai dengan hasil penelitian Aini dan Mulyono (2014), yang menyebutkan bahwa secara alamiah, mineral yang terdapat pada batuan akan melapuk seiring waktu, dengan pengaruh air, temperatur dan eksudrat yang dikeluarkan oleh makhluk hidup.

\section{Profil 4}

Profil 4 memiliki dua lapisan tanah sebelum lapisan bahan induk. Jenis mineral yang terdapat pada lapisan 1 profil 4 yaitu mineral liat (3B) umumnya berwarna coklat pada nikol silang, biotit (1D) yang berukuran kecil dan tersebar merata berwarna coklat kemerahan pada nikol silang dan coklat pada nikol sejajar. Kuarsa mendominasi persebaran mineral dengan ukuran yang lebih kecil, berwarna putih terang pada nikol silang dan tanpa warna pada nikol sejajar (Gambar 11).

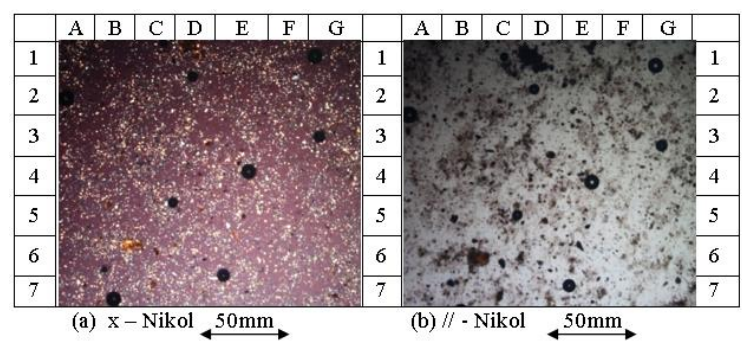

Gambar 11. (a) Sayatan tipis sampel tanah lapisan 1 profil 4 dengan nikol, (b) Sayatan tipis sampel tanah lapisan 1 profil 4 tanpa nikol. mineral liat (3B), dan biotit (1D). 
Jenis mineral yang terdapat pada lapisan 2 profil 4 yaitu Biotit (3C), (6F), berwarna coklat kemerahan pada nikol silang dan berwarna coklat pada nikol sejajar. Sedangkan mineral kuarsa berwarna putih terang dan berukuran kecil tersebar merata pada gambar. Mineral liat (4G), umumnya berwarna coklat pada nikol silang namun tidak memancarkan kilap (Gambar 12).

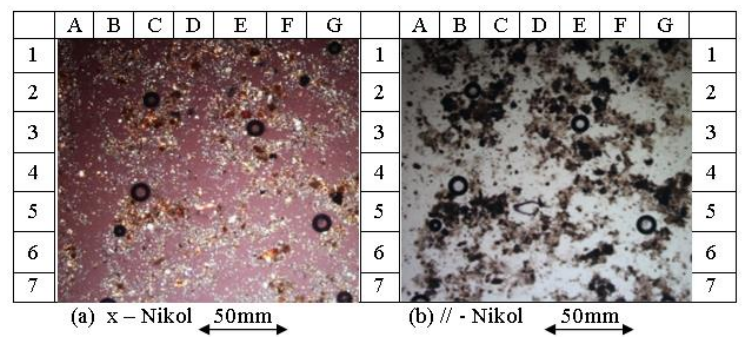

Gambar 12. (a) Sayatan tipis sampel tanah lapisan 2 profil 4 dengan nikol, (b) Sayatan tipis sampel tanah lapisan 2 profil 4 tanpa nikol. Biotit (3C), dan (6F), mineral liat $(4 \mathrm{G})$.

Berdasarkan hasil identifikasi mineral pada profil 4, maka persentase kandungan mineral ditunjukkan pada Tabel 13.

Tabel 13. Persentase kandungan mineral pada profil 4.

\begin{tabular}{|c|c|c|c|c|}
\hline $\begin{array}{l}\text { Kode } \\
\text { Profil }\end{array}$ & Lapisan & $\begin{array}{c}\text { Mineral } \\
\text { yang } \\
\text { Terkandung }\end{array}$ & $\begin{array}{l}\text { Kandungan pada } \\
\text { lapisan (\%) }\end{array}$ & Batuan Induk \\
\hline \multirow{6}{*}{ T1P4 } & & Biotit & 20 & \multirow{6}{*}{$\begin{array}{c}\text { Batupasir tufaan, batulanau, } \\
\text { batulempung, batugamping } \\
\text { pasiran dan konglomerat }\end{array}$} \\
\hline & 1 & Liat & 42 & \\
\hline & & Kuarsa & 38 & \\
\hline & \multirow{3}{*}{2} & Biotit & 30 & \\
\hline & & Kuarsa & 27 & \\
\hline & & Liat & 43 & \\
\hline
\end{tabular}

Dari hasil identifikasi mineral diketahui bahwa kandungan mineral pada lapisan satu profil 4 didominasi oleh mineral liat $42 \%$ dan biotit $20 \%$ yang memiliki sifat mudah lapuk dibandingkan mineral primer kuarsa. Sama halnya pada lapisan dua didominasi oleh mineral liat dan biotit yang banyak mengandung unsur hara seperti $\mathrm{K}$,
$\mathrm{Mg}$ dan Fe. Mineral biotit memiliki sifat yaitu sebagai mineral yang mudah lapuk, sehingga unsur-unsur yang terkandung didalamnya dapat dengan mudah diserap oleh tanaman jika terdapat air sebagai pembawa hara ke seluruh bagian tanaman.

\section{Profil 5}

Profil 5 terletak pada posisi lembah sehingga memiliki dua laipsan tanah sebelum lapisan bahan induk. Jenis mineral yang terdapat pada lapisan 1 adalah kuarsa (7D), opak (1E), biotit (7C) dan piroksin (2B). Kuarsa terlihat berwarna putih terang pada nikol silang dan tanpa warna pada nikol sejajar, Opak (mineral oksida, kaya mineral logam seperti besi) berwarna hitam dan biotit berwarna coklat baik pada nikol silang dan nikol sejajar. Mineral piroksin umumnya berwarna keunguan pada nikol silang dan tanpa warna pada nikol sejajar (Gambar 13).

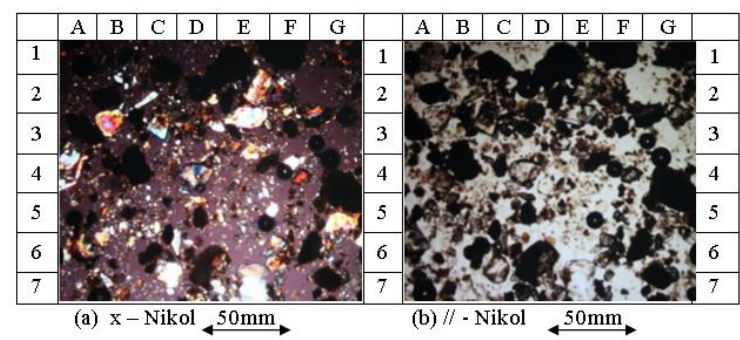

Gambar 13. (a) Sayatan tipis sampel tanah lapisan 1 profil 5 dengan nikol, (b) Sayatan tipis sampel tanah lapisan 1 profil 5 tanpa nikol. kuarsa (7D), opak (1E), biotit (7C) dan piroksin (2B).

Sedangkan pada lapisan 2 terdapat kalsit $(3 \mathrm{G})$, biotit (2A) dan kuarsa (2E). Namun, mineral yang terlihat pada lapisan dua ukurannya relatif lebih kecil dibandingkan lapisan pertama. Hal ini disebabkan karena profil 5 terletak pada topografi bagian lembah sehingga material padat seperti batuan pada profil yang letaknya dibagian lereng atau puncak terbawa kebawah sehingga menutupi lapisan top soil pada profil 5. Lambat laun bagian yang menutup lapisan ini akan melapuk dan terlihat seperti 
top soil. Hal ini juga diperkuat oleh pendapat Hardjowigeno (1993), pada tanah muda (perkembangan awal) terjadi proses pembentukan tanah terutama proses pelapukan bahan organik dan bahan mineral, pencampuran bahan organik dan bahan mineral di permukaan tanah dan pembentukan struktur tanah karena pengaruh dari bahan organik tersebut (sebagai perekat). Hasilnya adalah pembentukan horison A dan horison $\mathrm{C}$ (Gambar 14).

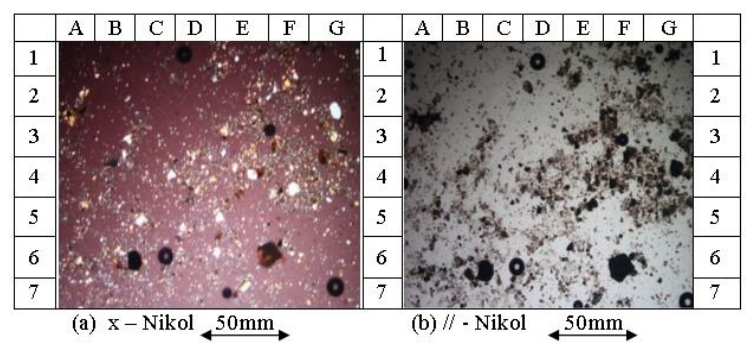

Gambar 14. (a) Sayatan tipis sampel tanah lapisan 2 profil 5 dengan nikol, (b) Sayatan tipis sampel tanah lapisan 2 profil 5 tanpa nikol. kalsit (3G), biotit (2A) dan kuarsa (2E).

Berdasarkan hasil identifikasi mineral pada profil 5, maka persentase kandungan mineral ditunjukkan pada Tabel 14.

Tabel 14. Persentase kandungan mineral pada profil 5.

\begin{tabular}{|c|c|c|c|c|}
\hline $\begin{array}{l}\text { Kode } \\
\text { Profil }\end{array}$ & Lapisan & $\begin{array}{c}\text { Mineral } \\
\text { yang } \\
\text { Terkandung }\end{array}$ & $\begin{array}{l}\text { Kandungan pada } \\
\text { Lapisan (\%) }\end{array}$ & Batuan Induk \\
\hline \multirow{8}{*}{ T1P5 } & \multirow{4}{*}{1} & Kuarsa & 21 & \multirow{8}{*}{$\begin{array}{c}\text { Batupasir tufaan, batulanau, } \\
\text { batulempung, batugamping } \\
\text { pasiran dan konglomerat }\end{array}$} \\
\hline & & Opak & 28 & \\
\hline & & Biotit & 32 & \\
\hline & & Piroksin & 19 & \\
\hline & \multirow{4}{*}{2} & Kalsit & 11 & \\
\hline & & Biotit & 19 & \\
\hline & & Kuarsa & 21 & \\
\hline & & Liat & 49 & \\
\hline
\end{tabular}

Data diatas menunjukkan bahwa kandungan mineral pada lapisan satu profil 5 didominasi oleh mineral biotit sebesar 32\% dan lapisan dua didominasi oleh mineral liat 49\% (Tabel 14). Mineral biotit dan mineral liat keduanya merupakan mineral mudah lapuk. Mineral dengan ciri mudah lapuk akan memudahkan tanaman dalam menyerap unsur hara yang terkandung apabila terdapat banyak air sebagai pembawa hara ke seluruh bagian tumbuhan. Dengan demikian dapat diasumsikan bahwa tanah pada profil 5 memiliki potensi hara yang baik bagi tanaman.

\section{Mineral Tanah pada Transek II}

\section{Profil 6}

Profil 6 memiliki satu lapisan tanah di atas bahan induk. Jenis mineral yang terdapat pada profil 6 antara lain biotit (5E) yang berwarna coklat kemerahan pada nikol silang dan coklat pada nikol sejajar. Mineral kuarsa berwarna putih terang pada nikol silang. Kalsit (4D) berwarna putih tulang pada nikol silang dan tanpa warna pada nikol sejajar. Mineral liat (4C) umumnya berwarna coklat pada nikol silang dan gelap pada nikol sejajar (Gambar 15).

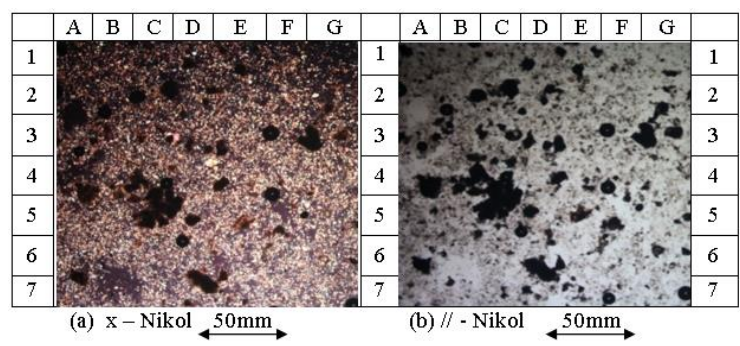

Gambar 15. (a) Sayatan tipis sampel tanah profil 6 dengan nikol, (b) Sayatan tipis sampel tanah profil 6 tanpa nikol. Biotit (5E), kalsit (4D), dan mineral liat (4C).

Berdasarkan hasil identifikasi mineral pada profil 6, maka persentase mineral ditunjukkan pada Tabel 15 .

Tabel 15. Persentase kandungan mineral pada profil 6.

\begin{tabular}{|c|c|c|c|c|}
\hline $\begin{array}{l}\text { Kode } \\
\text { Profil }\end{array}$ & Lapisan & $\begin{array}{c}\text { Mineral } \\
\text { yang } \\
\text { Terkandung }\end{array}$ & $\begin{array}{l}\text { Kandungan pada } \\
\text { Lapisan (\%) }\end{array}$ & Batuan Induk \\
\hline \multirow{4}{*}{ T2P6 } & \multirow{4}{*}{1} & Biotit & 16 & \multirow{4}{*}{$\begin{array}{c}\text { Batupasir tufaan, batulanau, } \\
\text { batulempung, batugamping } \\
\text { pasiran dan konglomerat }\end{array}$} \\
\hline & & Kalsit & 18 & \\
\hline & & Liat & 54 & \\
\hline & & Kuarsa & 21 & \\
\hline
\end{tabular}


Dari hasil identifikasi mineral diketahui bahwa kandungan mineral pada profil 6 didominasi oleh mineral biotit $16 \%$, kalsit $18 \%$, kuarsa $21 \%$ dan liat $54 \%$. Mineral kalsit dan biotit merupakan mineral sekunder yang memiliki sifat mudah lapuk dan menjadi mineral esensial untuk perkembangan dan kesuburan tanah. Jika dilihat hasil persentase kandungan mineral kalsit, pada lapisan bahan induk profil 6 mengandung $27 \%$ mineral kalsit. Hal ini menunjukkan bahwa terjadi proses pelapukan mineral kalsit menjadi mineral liat pada lapisan satu profil 6. Sehingga persentase kandungannya menurun.

Hasil ini juga didukung oleh data hasil analisis $\mathrm{pH}$ tanah pada profil 6 dengan nilai 7.64, memiliki kriteria agak alkalis. Hal ini sependapat dengan Yuliandini dan Putra (2013), yang menyatakan bahwa daerah yang tersusun atas batugamping memiliki $\mathrm{pH}$ yang mendekati basa dengan nilai $>7$, karena kaya akan unsur $\mathrm{Ca}^{++}$, selain itu beberapa tanah dengan kandungan batugamping memiliki nilai kapasitas tukar kation yang tinggi. Dengan demikian, dapat diasumsikan bahwa profil 6 memiliki potensi hara $\mathrm{Ca}, \mathrm{K}, \mathrm{Mg}$, Fe yang baik bagi tanaman.

\section{Profil 7}

Profil 7 memiliki satu lapisan tanah sebelum bahan induk. Jenis mineral yang banyak ditemui pada lapisan 1 profil 7 antara lain bioitit (5C), kuarsa (6E), kalsit (2G) dan mineral liat $(5 \mathrm{G})$. Mineral biotit berwarna coklat kemerahan pada nikol silang dan coklat pada nikol silang. Sedangkan kuarsa berwarna putih terang pada nikol silang dan tanpa warna pada nikol sejajar. Kalsit berwarna putih tulang pada nikol silang dan nikol sejajar. Mineral yang sulit dideskripsikan merupakan mineral liat pada sayatan tipis, umumnya berwarna kecoklatan (Gambar 16).

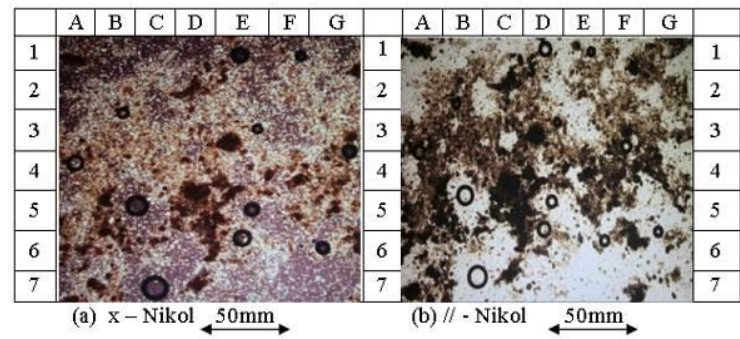

Gambar 16. (a) Sayatan tipis sampel tanah profil 7 dengan nikol, (b) Sayatan tipis sampel tanah profil 7 tanpa nikol. bioitit (5C), kuarsa (6E), kalsit (2G) dan mineral liat $(5 \mathrm{G})$.

Berdasarkan hasil identifikasi mineral pada profil 7, maka persentase kandungan mineral ditunjukkan pada Tabel 16.

Tabel 16. Komposisi kandungan hara pada profil 7.

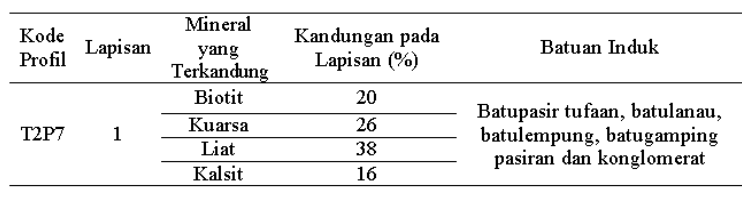

Berdasarkan hasil identifikasi mineral diketahui bahwa kandungan mineral pada profil 7 didominasi oleh mineral liat dengan persentase $38 \%$, mineral biotit $20 \%$, kalsit $16 \%$ dan kuarsa 26\%. Tingginya kandungan mineral liat pada profil 7 dikarenakan beberapa batuan induk pembentuk tanah profil 7 yaitu batulanau dan batulempung. Jika melihat profil 7 dengan Formasi Tmpm yang sama dengan formasi batuan profil 6, maka mengindikasikan adanya kandungan liat, yang menandakan terjadi pelapukan mineral primer. Hal ini pulalah yang menyebabkan pada profil 6 didominasi mineral liat. Jika dikalkulasikan, mineral mudah lapuk yang dikandung pada profil 7 yaitu sebesar $74 \%$. Maka dapat diasumsikan bahwa profil 6 memiliki potensi keharaan akan unsur $\mathrm{K}$, $\mathrm{Mg}, \mathrm{Fe}$ dan $\mathrm{Ca}$ yang tinggi. 


\section{Profil 8}

Profil 8 memiliki satu lapisan sebelum lapisan bahan induk. Mineral yang terdapat pada lapisan 1 profil 8 antara lain biotit (4B)(2D), kalsit (3F) dan kuarsa (4D). Biotit berwarna coklat kemerahan pada nikol silang berukuran cukup besar mendominasi pada sayatan tipis di profil 8. Kalsit berwarna putih baik pada nikol silang maupun nikol sejajar. Sedangkan kuarsa berwarna putih terang pada nikol silang berukuran kecil (Gambar 17).

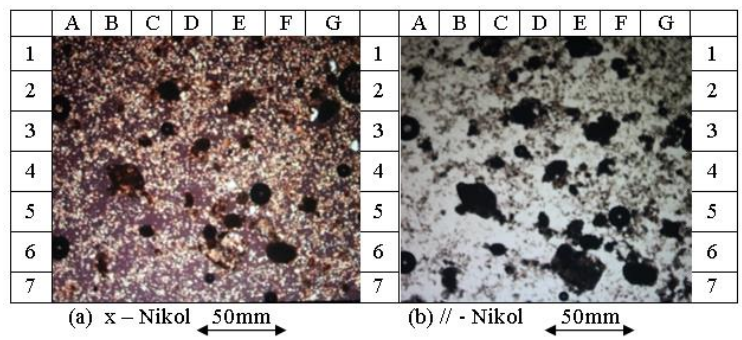

Gambar 17. (a) Sayatan tipis sampel tanah lapisan 1 profil 8 dengan nikol, (b) Sayatan tipis sampel tanah lapisan 1 profil 8 tanpa nikol. biotit (4B)(2D), kalsit (3F) dan kuarsa (4D).

Berdasarkan hasil identifikasi mineral pada profil 8, maka persentase kandungan mineral ditunjukkan pada Tabel 17.

Tabel 17. Persentase kandungan mineral pada profil 8 .

\begin{tabular}{|c|c|c|c|c|}
\hline $\begin{array}{l}\text { Kode } \\
\text { Profil }\end{array}$ & Lapisan & $\begin{array}{c}\text { Mineral } \\
\text { yang } \\
\text { Terkandung }\end{array}$ & $\begin{array}{l}\text { Kandungan pada } \\
\text { Lapisan (\%) }\end{array}$ & Batuan Induk \\
\hline \multirow{3}{*}{$\mathrm{T} 2 \mathrm{P} 8$} & \multirow{3}{*}{1} & Kalsit & 21 & \multirow{3}{*}{$\begin{array}{l}\text { Lempung lanau, pasir dan } \\
\text { kerikil }\end{array}$} \\
\hline & & Kuarsa & 52 & \\
\hline & & Biotit & 27 & \\
\hline
\end{tabular}

Dari hasil identifikasi mineral dapat diketahui bahwa kandungan mineral pada profil 8 didominasi oleh mineral kuarsa 52\%. Mineral kuarsa merupakan mineral tahan lapuk yang kurang bermanfaat bagi tanah dan tanaman, dianggap tidak memberikan kontribusi sebagai sumber hara tanah. Tanah pada profil 8 berwarna terang, hal ini mengindikasikan bahwa warna tanah yang terang berarti didominasi oleh mineral kuarsa. Hal ini sesuai dengan pendapat Hanafiah (2005) yang menyatakan bahwa indikator kesuburan tanah atau kapasitas produktivitas lahan dapat diketahui dengan kandungan bahan organik, intensitas pelindian dan kandungan kuarsa yang tinggi menyebabkan tanah berwarna lebih terang.

Selain itu, mineral kuarsa sebagai mineral dominan profil 8 ditandai dengan adanya batuan induk berupa batupasir. Hasil analisis tekstur dengan kriteria lempung liat berpasir juga menunjukkan, bahwa kandungan pasir sebanyak $70 \%$ menandakan bahwa profil 8 terdapat banyak kuarsa.

Namun, jika dibandingkan dengan hasil identifikasi mineral pada bahan induk dominan kalsit. Hal ini dikarenakan pada daerah profil 8 merupakan daerah alluvium, sehingga mineral yang terdapat pada lapisan-lapisan atas merupakan hasil dari proses pengendapan. Dari penjelasan diatas, dapat diasumsikan bahwa tanah pada lapisan 1 profil 8 persentasi $48 \%$ dengan kriteria keharaan sedang.

\section{Profil 9}

Profil 9 terdapat pada posisi lembah sehingga memiliki dua lapisan tanah. Jenis mineral yang terdapat pada lapisan 1 profil 9 didominasi oleh kuarsa (1B) dan liat (2C). Kuarsa berwarna putih terang yang berukuran kecil dan tersebar merata pada sayatan tipis. Mineral liat pada gambar umumnya berwarna coklat pada penampakan nikol silang (Gambar 19).

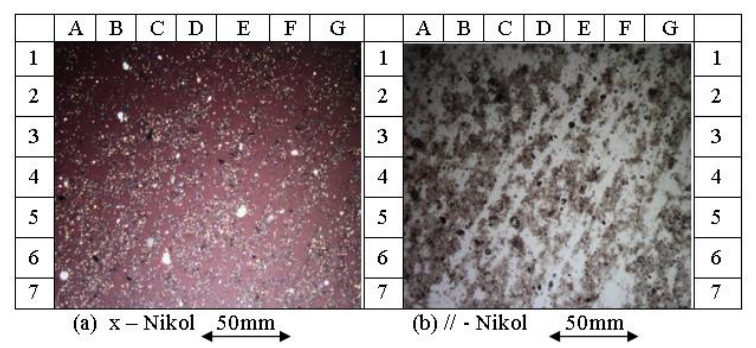

Gambar 19. (a) Sayatan tipis sampel tanah profil 9 lapisan 1 dengan nikol. kuarsa (1B) dan liat (2C). 
Mineral yang terdapat pada lapisan 2 profil 9 antara lain biotit (2D), kuarsa (7B), hornblende (7D), opak (6B) dan mineral liat (1G). Biotit berwarna coklat kemerahan pada nikol silang dan coklat pada nikol sejajar. Kuarsa berwarna putih terang pada nikol silang dan tanpa warna pada nikol sejajar. Hornblende pada lapisan ini berwarna biru cerah jika dilihat pada nikol silang, namun tanpa warna pada nikol sejajar. Sedangkan mineral opak berwarna hitam pada nikol silang maupun sejajar (Gambar 20).

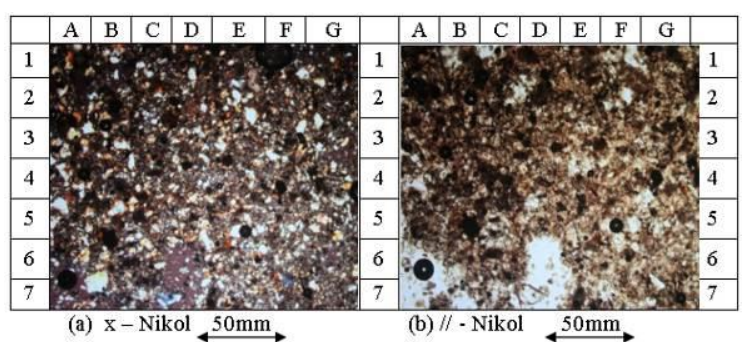

Gambar 20. (a) Sayatan tipis sampel tanah profil 9 lapisan 2 dengan nikol, (b) Sayatan tipis sampel tanah profil 9 lapisan 2 tanpa nikol. biotit (2D), kuarsa (7B), hornblende (7D), opak (6B) dan mineral liat $(1 \mathrm{G})$.

Berdasarkan hasil identifikasi mineral pada profil 9, maka persentase kandungan mineral ditunjukkan pada Tabel 19.

Tabel 19. Persentase kandungan mineral pada profil 9.

\begin{tabular}{|c|c|c|c|c|}
\hline $\begin{array}{l}\text { Kode } \\
\text { Profil }\end{array}$ & Lapisan & $\begin{array}{c}\text { Mineral } \\
\text { yang } \\
\text { Terkandung }\end{array}$ & $\begin{array}{c}\text { Kandungan pada } \\
\text { Lapisan (\%) }\end{array}$ & Batuan Induk \\
\hline \multirow{6}{*}{ T2P9 } & \multirow{2}{*}{1} & Kuarsa & 32 & \multirow{6}{*}{$\begin{array}{l}\text { Lempung lanau, pasir dan } \\
\text { kerikil }\end{array}$} \\
\hline & & Liat & 68 & \\
\hline & \multirow{4}{*}{2} & Liat & 43 & \\
\hline & & Kuarsa & 35 & \\
\hline & & Hornblende & 10 & \\
\hline & & Opak & 12 & \\
\hline
\end{tabular}

Dari hasil identifikasi mineral diatas dapat diketahui bahwa kandungan mineral pada profil 9 didominasi oleh mineral liat sebesar $68 \%$ dan kuarsa 32\%. Menurut Ibrahim dan Ahmad (2012), mineral liat merupakan mineral ubahan dari mineral primer maupun hasil pembentukan baru pada saat proses pembentukan tanah. Mineral liat termasuk kedalam jenis mineral sekunder yang mudah mengalami pelapukan.

Hal ini diperkuat dari data analisis tekstur berupa liat dengan persentase liat sebesar 96\% pada lapisan 1 dan kriteria tekstur berupa liat berdebu dengan persentase debu 54\% pada lapisan 2. Profil 9 merupakan daerah kondisi drainase yang buruk karena merupakan daerah rawa, sehingga kandungan bahan organiknya rendah sampai sedang yaitu berkisar antara $1.87 \%$ sampai $2.20 \%$. Dengan demikian, dapat diasumsikan bahwa profil 9 memiliki potensi kandungan hara yang rendah.

\section{Mineral tanah pada Transek III}

\section{Profil 10}

Profil 10 memiliki satu lapisan tanah sebelum lapisan bahan induk (Gambar 31). Mineral yang terdapat pada lapisan 1 profil 10 yaitu biotit (3E), mineral liat (6C), piroxin (5D) dan kuarsa (7D). Mineral biotit berwarna coklat kemerahan pada nikol silang dan berwarna coklat pada nikol sejajar serta ukurannya lebih besar dibandingkan mineral kuarsa. Mineral piroxin berwarna kuning kecoklatan pada nikol silang dan coklat pada nikol sejajar. Mineral liat pada penampakan sayatan tipis umumnya berwarna coklat. Sedangkan kuarsa berwarna putih terang pada nikol silang dan tak berwarna pada nikol sejajar (Gambar 21).

Berdasarkan hasil identifikasi mineral pada profil 10, maka persentase kandungan mineral ditunjukkan pada Tabel 20 . 


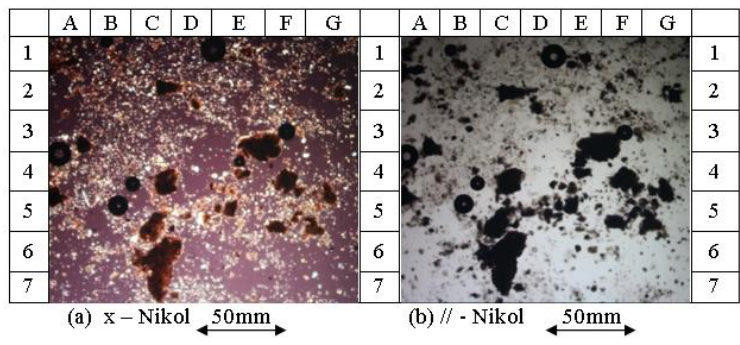

Gambar 21. (a) Sayatan tipis sampel tanah profil 10 lapisan 1 dengan nikol, (b) Sayatan tipis sampel tanah profil 10 lapisan 1 tanpa nikol. biotit (3E), mineral liat (6C), piroxin (5D) dan kuarsa (7D).

Tabel 20. Persentase kandungan mineral pada profil 10.

\begin{tabular}{|c|c|c|c|c|}
\hline $\begin{array}{l}\text { Kode } \\
\text { Profil }\end{array}$ & Lapisan & $\begin{array}{c}\text { Mineral } \\
\text { yang } \\
\text { Terkandung }\end{array}$ & $\begin{array}{l}\text { Kandungan pada } \\
\text { Lapisan (\%) }\end{array}$ & Batuan Induk \\
\hline \multirow{4}{*}{ T3P10 } & \multirow{4}{*}{1} & Biotit & 17 & \multirow{4}{*}{$\begin{array}{c}\text { Napal tufaan, serpih napalan, } \\
\text { batupasir tufaan, lensa-lensa } \\
\text { konglomerat }\end{array}$} \\
\hline & & Kuarsa & 32 & \\
\hline & & Liat & 38 & \\
\hline & & Piroxin & 13 & \\
\hline
\end{tabular}

Berdasarkan hasil identifikasi mineral diketahui bahwa mineral pada profil 10 lapisan 1 didominasi oleh mineral liat dengan persentase 39\% namun hasilnya tidak jauh berbeda dengan persentase mineral kuarsa sebesar 32\%. Hal ini diperkuat dengan hasil analisis tekstur berupa lempung liat berpasir dengan persentase pasir sebesar 53\%. Hal ini sependapat dengan Saptaningsih (2007), menyatakan bahwa tanah pasir yang didominasi oleh mineral primer seperti kuarsa $\left(\mathrm{SiO}_{2}\right)$, tahan terhadap pelapukan dan tidak mampu menyediakan unsur-unsur hara bagi tanaman.

Jika dibandingkan dengan mineral pada lapisan bahan induk profil 10 yang didominasi oleh mineral biotit sebesar 37\%, maka adanya mineral liat pada lapisan 1 profil 10 diasumsikan merupakan ubahan dari mineral awalnya. Pada lapisan 1 mineral liat pada lapisan ini diindikasikan juga sebagai hasil pelapukan dari mineral primer yang dikandung pada profil 10 yaitu piroxin dan biotit. Jika dikuantifikasikan maka pada profil ini kandungan mineral mudah lapuk sebesar $67 \%$, yang berarti potensi unsur hara $\mathrm{K}, \mathrm{Mg}, \mathrm{Fe}$ dan $\mathrm{Ca}$ agak tinggi.

\section{Profil 11}

Profil 11 memiliki dua lapisan sebelum lapisan bahan induknya. Jenis mineral yang terdapat pada lapisan 1 profil 11 antara lain kuarsa (7D), biotit (3E) dan mineral liat. Kuarsa berwarna putih terang pada nikol silang dan tanpa warna pada nikol sejajar, kuarsa tersebar dengan ukuran kecil pada sayatan tipis lapisan 1 profil 11. Biotit memiliki ukuran lebih besar dibandingkan mineral lainnya dengan warna coklat kemerahan pada nikol silang dan coklat pada nikol sejajar. Sedangkan mineral liat diasumsikan bagi mineral yang sulit diidentifikasi pada nikol silang dan nikol sejajar (Gambar 22).

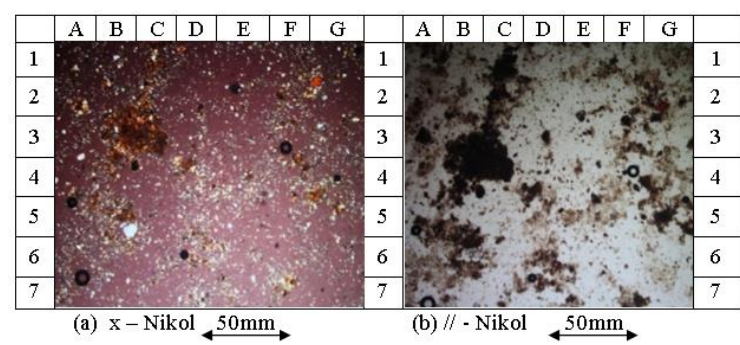

Gambar 22. (a) Sayatan tipis sampel tanah profil 11 lapisan 1 dengan nikol, (b) Sayatan tipis sampel tanah profil 11 lapisan 1 tanpa nikol. Kuarsa (7D), dan biotit (3E)

Jenis mineral yang terdapat pada lapisan 2 profil 10 antara lain biotit (2E)(2B) dan kuarsa $(5 \mathrm{~A})$. Biotit memiliki ukuran lebih besar dibandingkan dengan mineral kuarsa. Hal ini disebabkan karena biotit yang merupakan mineral primer pada proses pembentukannya lebih dulu terbentuk dibanding kuarsa, namun kuarsa memiliki daya ketahanan yang lebih kuat daripada biotit. Sehingga bentuknya akan tetap bertahan, namun biotit seiring perkembangan tanah akan mengalami 
pengurangan ukuran sebagai mineral yang mudah lapuk (Gambar 23).

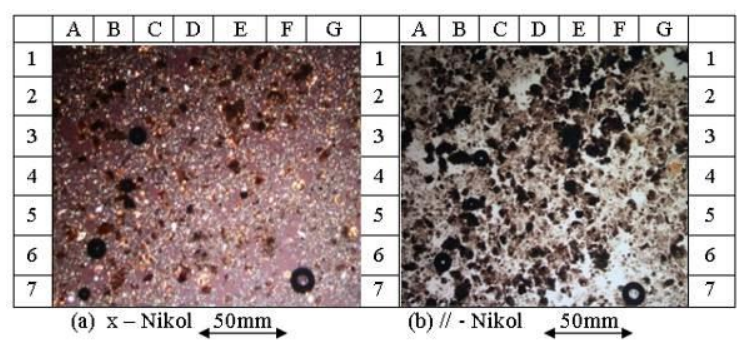

Gambar 23. (a) Sayatan tipis sampel tanah Profil 11 lapisan 2 dengan nikol, (b) Sayatan tipis sampel tanah Profil 11 lapisan 2 tanpa nikol. Biotit $(2 \mathrm{E})(2 \mathrm{~B})$ dan kuarsa (5A).

Berdasarkan hasil identifikasi mineral pada sampel tanah profil 11, maka persentase kandungan mineral ditunjukkan pada Tabel 21.

Tabel 21. Persentase kandungan mineral pada profil 11.

\begin{tabular}{|c|c|c|c|c|}
\hline $\begin{array}{l}\text { Kode } \\
\text { Profil }\end{array}$ & Lapisan & $\begin{array}{l}\text { Mineral } \\
\text { yang } \\
\text { Terkandung }\end{array}$ & $\begin{array}{c}\text { Kandungan pada } \\
\text { Lapisan (\%) }\end{array}$ & Batuan Induk \\
\hline \multirow{8}{*}{ T3P11 } & & Kalsit & 8 & \multirow{8}{*}{$\begin{array}{c}\text { Batupasir tufaan, batulanau, } \\
\text { batulempung, batugamping } \\
\text { pasiran dan konglomerat }\end{array}$} \\
\hline & 1 & Kuarsa & 32 & \\
\hline & & Biotit & 21 & \\
\hline & & Liat & 39 & \\
\hline & \multirow{4}{*}{2} & Biotit & 37 & \\
\hline & & Kuarsa & 33 & \\
\hline & & Liat & 18 & \\
\hline & & Kalsit & 12 & \\
\hline
\end{tabular}

Dari hasil identifikasi mineral dapat diketahui bahwa kandungan mineral pada lapisan satu adalah mineral liat dengan persentase $39 \%$ dan lapisan dua didominasi mineral biotit dengan persentase $37 \%$. Biotit dan mineral liat merupakan mineral dengan sifat mudah lapuk. Mineral biotit merupakan kelompok mika ini merupakan mineral yang banyak mengandung unsur hara yang dibutuhkan oleh tanaman seperti unsur Kalsium (K), Magnesium (Mg) dan Besi (Fe). Menurut Aini dan Mulyono (2014), dalam penelitiannya menyebutkan bahwa pada tanah-tanah yang banyak mengandung mineral yang sangat mudah lapuk (early weathering stages) menunjukkan bahwa tanah tersebut masih muda atau belum mengalami pelapukan lanjut. Sedangkan mineral liat merupakan ubahan dari mineral primer yang terdapat pada profil ini yaitu mineral biotit. Maka dapat diasumsikan bahwa profil 11 memiliki potensi keharaan yang sedang.

\section{Hubungan Mineral Terhadap Potensi Kesuburan Tanah}

Secara umum, batuan mengandung mineral tertentu maupun kumpulan mineral yang mempunyai potensi keharaan cukup besar yang dapat dimanfaatkan oleh tanaman adalah dalam bentuk mineral mudah lapuk (weatherable mineral). Dalam melakukan penilaian terhadap penentuan potensi kesuburan tanah pada tiap profil dalam penelitian ini mengacu kepada hasil identifikasi mineral pada masing-masing profil di tiap transek (Tabel 22).

Tabel 22. Jenis-jenis mineral yang ditemui pada lokasi penelitian.

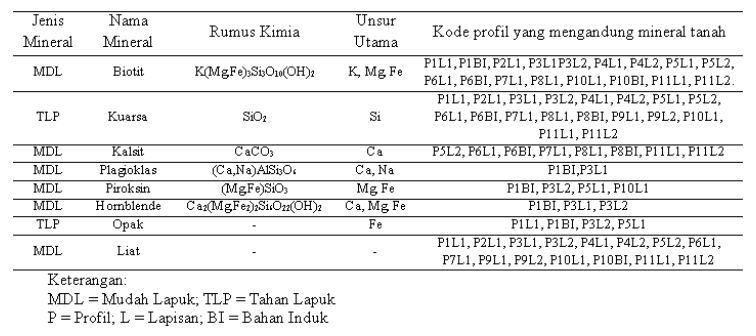

Dari hasil tabel diatas menunjukkan bahwa pada lokasi penelitian banyak terdapat mineral primer yang mudah lapuk. Mineral yang paling sering ditemui adalah mineral biotit, kuarsa, kalsit dan mineral liat. Namun, telah dijelaskan diatas bahwa mineral dengan sifat mudah lapuk (weatherable mineral) yang dapat berperan sebagai penyedia hara dalam tanah. Menurut Pramuji dan Bastaman (2009), tanah yang didominasi oleh mineral seperti kuarsa dan opak tidak dapat memberikan kontribusi sebagai sumber hara tanah.

Potensi cadangan hara di tanah dapat dihitung berdasarkan besar kecilnya 
kandungan mineral kuarsa (Notohadiprawiro, 1983) (Tabel 23).

Tabel 23. Potensi cadangan hara pada lokasi penelitian.

\begin{tabular}{cccc}
\hline $\begin{array}{c}\text { Kode } \\
\text { Profil }\end{array}$ & $\begin{array}{c}\text { Kandungan Kuarsa } \\
\text { (\%) }\end{array}$ & $\begin{array}{c}\text { Cadangan Hara } \\
\text { (\%) }\end{array}$ & Kriteria \\
\hline P1L1 & 31 & 69 & Sedang \\
\hline P1BI & 30 & 70 & Sedang \\
\hline P2L1 & 38 & 62 & Sedang \\
\hline P3L1 & 27 & 73 & Baik \\
\hline P3L2 & 21 & 79 & Baik \\
\hline P4L1 & 38 & 62 & Sedang \\
\hline P4L2 & 27 & 73 & Baik \\
\hline P5L1 & 21 & 79 & Baik \\
\hline P5L2 & 21 & 79 & Baik \\
\hline P6L1 & 21 & 79 & Baik \\
\hline P6BI & 52 & 48 & Sedang \\
\hline P7L1 & 26 & 74 & Baik \\
\hline P8L1 & 52 & 48 & Sedang \\
\hline P8BI & 40 & 60 & Sedang \\
\hline P9L1 & 32 & 68 & Sedang \\
\hline P9L2 & 25 & 75 & Baik \\
\hline P10L1 & 32 & 68 & Sedang \\
\hline P10B1 & 33 & 67 & Sedang \\
\hline P11L1 & 32 & 68 & Sedang \\
\hline P11L2 & 33 & 67 & Sedang \\
\hline
\end{tabular}

potensi banyaknya unsur hara yang terkandung pada beberapa profil masih dalam keadaan kurang tersedia, karena kurang didukung oleh faktor eksternal seperti ketersediaan air yang rendah. Potensi iklim daerah penelitian berada pada kisaran 949.0 sampai $2557.1 \mathrm{~mm} /$ tahun dengan ratarata curah hujan tahunan $1608.0 \mathrm{~mm} / \mathrm{tahun}$.

\section{KESIMPULAN}

Berdasarkan hasil dan pembahasan penelitian, maka diperoleh kesimpulan yaitu:

1. Mineral-mineral yang terdapat pada lokasi penelitian umumnya merupakan mudah lapuk, antara lain biotit, kalsit, plagioklas, piroksin dan hornblende.

2. Mineral mudah lapuk yang banyak dijumpai pada lokasi penelitian menandakan bahwa daerah penelitian memiliki potensi kesuburan tanah dan belum mengalami tingkat pelapukan tanah lanjut. Potensi kesuburan pada bahan induk tanah berada pada kriteria sedang (48\% sampai 70\%), sedangkan pada tanah berada pada kriteria sedang (48\% sampai $70 \%$ ) dan kriteria baik
(73\% sampai 79\%), sedangkan persentase mineral kuarsa $21 \%$ sampai $52 \%$.

3. Adapun beberapa potensi unsur hara yang terdapat pada lokasi penelitian yaitu $\mathrm{Mg}, \mathrm{K}, \mathrm{Ca}, \mathrm{Fe}$ dan Na. Namun banyaknya unsur hara yang terkandung pada beberapa profil masih dalam keadaan kurang tersedia, karena kurang didukung oleh faktor eksternal seperti ketersediaan air yang rendah. Hal ini sejalan dengan potensi iklim yang berada pada kisaran 949.0 sampai $2557.1 \mathrm{~mm} /$ tahun dengan rata-rata curah hujan tahunan $1608.0 \mathrm{~mm} /$ tahun.

\section{PUSTAKA}

Aini, L. Noer dan Mulyono. 2001. Kajian Kandungan Material Vulkanik Gunung Api Guna Peningkatan Kualitas Lahan, Laporan Penelitian Unggulan Program Studi. Yogyakarta: Universitas Muhammadiyah Yogyakarta.

Alam, S. et al., 2012. Karakteristik Bahan Induk Tanah dari Formasi Geologi Kompleks Ultramafik di Sulawesi Tenggara. Jurnal Agroteknologi Vol. 2, No. 2, Hal 112-120

Alimudi, Z. Fauzi. 2014. Analisis Mikromorfologi Tanah pada Kaki Lereng Gunung Lpmpobattang (Arah Barat Barat Laut - Timur Menenggara) di Kabupaten Bulukumba, Skripsi. Makassar: Universitas Hasanuddin.

Djuhariningrum, T., Rusmadi. 2004. Penentuan Kalsit dan Dolomit Secara Kimia dalam Batu Gamping dari Madura. Pusat Pengembangan Geologi Nuklir-Batan. ISBN. 978979-99141-2-5. 
Djuri, Sudjatmiko et al., 1998. Geologi Lembar Majene dan Bagian Barat Palopo, Sulawesi (Edisi Kedua).

Hanafiah, A. Kemas. 2005. Dasar-dasar Ilmu Tanah. Rajagrafindo Persada. Jakarta.

Hardjowigeno, S., 1993. Klasifikasi Tanah dan Pedogenesis. Akademika Pressindo. Jakarta.

Ibrahim, B. dan Ahmad, Asmita. 2012. Agrogeologi dan Mineralogi Tanah. Buku Ajar. Makassar: Universitas Hasanuddin.

Lahuddin. 2007. Aspek Unsur Mikro dalam Kesuburan Tanah. USU e-Repository. Universitas Sumatera: Medan.

Notohadiprawiro, Tetjoyuwono. 1983. Selidik Cepat Ciri Tanah Di Lapangan. Ghalia Indonesia. Yogyakarta.

Pemkab Majene. 2012. Buku Putih Sanitasi Kabupaten Majene. POKJANIS PPSP Kabupaten Majene. Sulawesi Barat.

Pramuji dan Bastaman, M., 2009. Teknik Analisis Mineral Tanah untuk Menduga Cadangan Sumber Hara. Buletin Teknik Pertanian Vol. 14, No. 2, 2009: 80-82.

Saptiningsih, E. 2007. Peningkatan Produktivitas Tanah Pasit untuk Pertumbuhan Tanaman Kedelai dengan Inokulasi Mikorizha dan Rizhobium. Bioma 9:58.

Sugiharyanto dan Khotimah, Nurul. 2009. Diktat Mata Kuliah Geografi Tanah. Universitas Negeri Yogyakarta: Yogyakarta.

Van Zuidam, R. A.., 1985. Aerial Photo Interpretation in Terrain Analysis and
Geomorphologic Mapping. Smith Publisher, The Hague, ITC.

Warmana, W. dan Titisari, A. Dewi. 2004. Agromineralogi (Mineralogi untuk Ilmu Pertanian). Universitas Gadjah Mada. Yogyakarta. 